\title{
The Impact of Human Resource Management (Hrm) Practices on Labour Productivity in Libyan National Oil Corporations: The Mediating Role of Social Skills
}

\author{
PhD Candidate. Mohamed Ibrahim Mohamed Abulkasim
}

(Corresponding author), Faculty of leadership and management, University Sains Islam Malaysia Email:usimthebest@yahoo.com.my

Dr. Mahazan Abdul Mutalib

Faculty of leadership and management, UniversitySains Islam Malaysia Email:mahazan@usim.edu.my

Prof. Dr Adel M. Abdulaziz

Islamic University of Malaysia; Email: adel@uim.edu.my

Dr. Mikail Ibrahim

Faculty of Major Languages Studies; Email:mikail@usim.edu.my

Doi:10.5901/mjss.2016.v7n2p201

\section{Abstract}

This study evaluated the links between HRM practices and Labour productivity comprehensively with the mediating role of social skills. The study focuses on the Libyan oil and gas companies that play an important role in Libya's economic development. The data of this study were collected using the quantitative approach, whereby the questionnaire was administered and yielded 339 respondents with a response rate of $56.5 \%$. Results based on these practices have significant impact on both social skills and labour productivity. Finally, the roles of staffing and on-the-job training as HRM practices contradict the results of previous studies that found these factors to be crucial for labour productivity. This study suggests that decentralised decisions lies in the strategic models and enables the HRM policies to be in force.

Keywords: HRM practices, social skills, labour productivity, Structural equation modelling

\section{Introduction}

HRM practices in the oil and gas sector especially in an emerging and developing country like Libya are of primary importance due to the huge reliance of its economy accounting for over $90 \%$ of the country's GDP. According to (Huselid, 1995), "There is a rising agreement among the researchers that organisational human resource policies can improve labour Productivity and organisational objectives like productivity and sale".

Evidence of shortcomings in standard HR practices and reduced labour competency necessitate investigation of the productivity of employees within oil producing companies in terms of HR practices. This helps identify key problems and suggests ways to resolve it. Human resource management are not solely to blame for the reduction in oil production. There are many other reasons and issues for low extraction including political instability, low country reputation, market demand and supply, macro-economic consequences, technological and social issues, along with investment opportunities. At this stage, it is not possible for the research to focus on all the aspects and issues related to oil production and extraction. The gap in studies on the relation of HR practices to low labour productivity forms the main concern of this study. As a sole dominant exporting product and major source of export revenue for the Libyan economy, the investigation of causes for deficiencies in HR practices and their impact of labour productivity through the mediating effect of social skills is important. Analysing the efficiencies in HR practices and their impact on labour productivity is a central question that will assist in identifying the factors causing low labour productivity in oil companies in Libya. This investigation can help in designing optimal policy agenda to stabilise production and suggest ways for further improvement the production of oil through improving HR practices and labour productivity. 


\subsection{Industry overview}

The oil and gas sector plays a dominant role in the Libyan economy. Since 1958, the sector has undergone a series of developments. Libya first gave permission to international companies to extract oil in 1955 (Abozed, Melaine, \& Saci, 2009) and in 1961 Libyan oil was exported and traded internationally (Bindra, 2008; RoudiFahimi and Kent, 2007). Libya became the sixth largest country for oil production and since 1968 the sector and subsidiary companies have been managed by the National Oil Corporation (NOC) (Abozed et al., 2009). NOC has handled the production and selling of oil in the global marketplace from 1968 till present. However, (Bindra, 2008) mentioned that during the 1992 to 1999 period, sanctions led to reduced oil and gas production.

Libya has the largest proven oil reserve in Africa and is one of the top influential countries of the Organisation of the Oil Exporting Countries (Annual statistical bulletin, 2012). Unfortunately, in spite of these facts the average oil production of Libya is volatile and has seen a decreasing trend (Outlook, 2013). The Libyan economy is highly dependent on hydrocarbons for export earnings. The U.S. Department of State concluded that Libya's oil export earns about $95 \%$ of its total export earnings, $75 \%$ of government earnings, and 25\% of its GDP before the political unrest took place in 2011 (Outlook, 2013). The oil and gas sector added up to $71 \%$ in 2007 and $97 \%$ in 2009 of the total export earnings to the Libyan economy (Mobbs, Taib, \& Wallace, 2012).

The proven oil reserve of the country has increased while surprisingly the production of all kinds of petroleum products (which is considered as organisational output) decreased in Libya in 2012 compared to 2011 (Outlook, 2013). Notwithstanding, the percentage reduction in petroleum products is remarkable as compared to other African countries, particularly with Nigeria which a close competitor of Libya in terms of petroleum products (Outlook, 2013). Similarly, the average production of crude oil of Libya is also decreasing in the OPEC members. In 1970, the capacity of Libya was $33,180,000$ barrels. Subsequently, the production of crude oil has decreased to $18,316,000$ barrels in 1980 . The annual statistical report of OPEC (2012) shows that the production of crude oil is 4,895,000 barrels per day which is only $14 \%$ compared to the 1970 average daily crude oil production. The capacity of the country is around 16 million barrels per day. Although the hydrocarbon sector contributes $95 \%$ to total exports, labour productivity in the oil sector has been heavily affected due to lack of accurate Human Resource (HR) practices for the extraction of crude oil and its management (Bindra, 2008).

\section{Review of Literature}

\subsection{HRM practices}

In order to achieve organisational objectives, there have been many empirical investigations that focused on individual HRM practices. Studies like (Huselid, 1995; Koch \& Mcgrath, 1996) support the importance of HRM practices on increasing total firm productivity. (Koch \& Mcgrath, 1996) mentioned that, "training has an immediate effect on the labour productivity", whereas according to (Delaney \& Huselid, 1996), "information sharing has positive influence on productivity". (Bloom \& Reenen, 2011; Delaney \& Huselid, 1996; Park \& Shaw, 2013) concluded that HR practices have a positive influence on organisational outcomes across countries. Even though many studies discussed the linkage between HRM practices and labour productivity, revenue and performance, other studies were critical of the relationship (Ruël \& Bondarouk, 2014; Tharenou, Saks, \& Moore, 2007; Woodrow \& Guest, 2014) citing concerns over the methods employed to determine the relationship between HRM practices and labour productivity. Thus it is a challenging issue to compare the findings across studies with the acceptable HRM practices for enhancing employee labour productivity and organisation outcomes (Delaney \& Huselid, 1996; Huselid, 1995).

\subsection{Social Skills as Mediator}

Several studies have been conducted on the relationship between HRM and productivity (Barney, 1991; Wright \& McMahan, 1992). The results of previous studies like indicated that HRM influences productivity (Ruël \& Bondarouk, 2014; Tharenou et al., 2007; Woodrow \& Guest, 2014). However, these studies ignored the role of the mediating effects of social skills, which clearly refer to the absence of the causal relationship between the previous mentioned variables. Additionally, some studies have found that HRM can affect the social skills (Aggarwal and Bhargava 2009; Thongsennheuang (2012) and that social skills could influence productivity (Ashkanasy, and Hartel, 2002; Goleman,1998). More recently, it has become obvious that the effectiveness of HRM as far as production is concerned heavily depends on social skills. The acquisition of social skills such as the collaboration and development of social 
networks has been referred to as a 'toolbox' of interventions in HRM. This should form part of a sound theoretical and research based understand to explain the working environment and to formulate plans of action appropriate to counter the myriad of limitations affecting labour productivity (Trevithick, 2000). However, this involves a clear understanding of how experiences are communicated by people and knowledge of how it effects behaviour and life situations, especially in work environments.

To a reasonable extent, understanding social skills will always be incomplete without collaboration and networking because in the realm of human experience, life is unpredictable and some uncertainty is inevitable (Tsang, 2003). Improving HRM practices and administrative skills based on the context of the current research with respect to previous evidence available is a difficult task (McGurk, Mueser, \& Pascaris, 2005). Nonetheless, studies have suggested using social skills as mediating the relationship between HRM practices and administrative skills (Tharenou et al., 2007, Baron and Kenny's 1986).Finally, to enhance labour productivity in Libya requires a careful integration of social skills as well as strategic implementation of the key HRM practices especially staffing, on-the-job training, decentralised decisions, and employee motivation that contribute towards enhancing labour productivity.

\subsection{Labor Productivity}

As defined by (Thomas et al., 1990) "Productivity is the rate at which outputs of goods and services are produced per unit of input such as labour, capital, raw materials". This can be computed by the ratio of outputs to inputs. This may be applied to measure the productivity of firms, industries and even the economy as a whole. Based on the situation and the choice of input and output measures, different meanings from the productivity calculation can be implied. The general idea of productivity refers to the technical production relationships between inputs and outputs. However, the underlying idea of this term may also be about the production of desired, valued, as well as demanded goods and services. Productivity can be expressed as a physical measure, a monetary measure, or an index. Within this specified measure, inputs can be broadly defined.

Among all other types of productivity measures, labour productivity is exceptionally important in the economic and econometric analysis of a country because it indicates the dynamic measure of economic growth, competitiveness, and living standards within an economy (McGuckin \& Van Ark, 2003). The measurement of labour productivity is essential especially in the Human Resource Management (Fletcher, 2001). Historically, organisations have always come out with methods to measured performances (Fletcher, 2001). However, traditional performance measures, which are based on cost accounting information, only serve organisations in little way to determine organisation's quality journey.

Labour productivity through the HR structure may contribute to the organisational capabilities. The employees in an organisation play a vital role to determine the organisational objectives. The employees help to achieve a desired goal not the organisation by itself which signify the role of employees (Kozlowski \& Klein, 2000). This shows a link between HR practices and organisational goal through labour productivity.

\section{Model Development}

\subsection{Background of the model}

Figure 1 presents the research model. Consistent with the approach of Masood (2010), we draw the model keeping in view the research by (Aggarwal and Bhargava 2009; Thongsennheuang (2012). Aggarwal and Bhargava (2009) and Thongsennheuang (2012) suggest that organisational outcomes are a direct function of HR practices such as training and managerial skills which are influenced by the social skills of employees. Social skills play an important role as a mediating variable. It has an assisting effect, which contributes towards a positive behaviour effect on labour productivity (Hogan \& Shelton, 1998).

Figure 1: Research Model

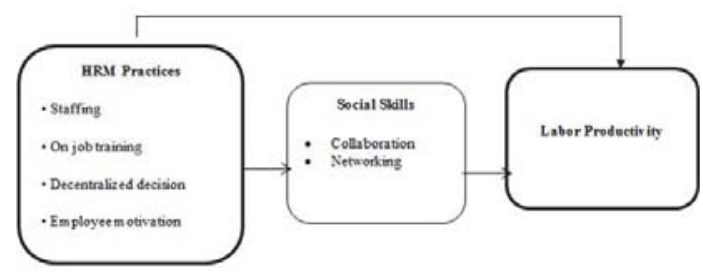


Organisational objectives are dependent on many factors such as the stock of human and financial capital, the portfolio of human capital, the production technique, scale of production, status of technology, macroeconomic factors and political and economic stability of the country (Arnold \& Feldman, 1982; Bassanini, Garnero, Marianna, \& Martin, 2010; Fallahi, Sakineh, \& Mehin Aslaninia, 2010; Hank, 2011). However, this study focuses on the HR practices, to gauge the cause of low labour productivity in the selected Libyan oil and gas companies, while the rest of the factors such as technological, political, and macroeconomic environment fall outside the scope of this study. Thus the main research hypotheses are:

H1: There is a positive relationship between HR practices and labour productivity.

H2: HRM practices is positively related to social skills of the employees.

H3: HRM practices and labour productivity is mediated positively by social skills

However, integrating HRM into organisation's strategy and applying specific sets of human resource (HR) policies and practices introduces complexities in managing employees effectively; therefore performance of individual and organisational could be hampered (Farnham, 2010; Holbeche, 2009). Social skills have been narrowly reported in economic sociology with focus on behavioural interactions (Ogden \& Goldberg, 2002). However, no study has been conducted on social skills in Libyan oil companies. According to the sociologist Mark Granovetter, social structure, pay for performance, asymmetric information quality, and employee trust are the core principles of social skills (Boxall \& Purcell, 2011). The main concern of the study is to explain and attempt to fill the theoretical and practical gaps in HRM.

\subsection{Sampling}

The research sample is limited to the following Libyan oil companies: 1) Waha Oil Company (WOC), 2) Arabian Gulf Oil Company (AGOCO), and 3) Sirte Oil Company (SOC). These are the leading government owned oil companies working under the National Oil Commission (NOC) of Libya. The selected companies represent $70 \%$ of the total oil sector output. A survey is administered to get data through questionnaires from 378 employees, working in the sampled companies. After removing outliers from the data and data screening, finally 339 samples were considered for the data analysis. The goal of this survey is investigate the research questions in the proposed context.

\section{Data Analysis}

Table 1 provides the individual respondents' profiles in terms of gender, job status, qualification, income and experience. 290 out of 339 respondents (85.55\%) were males, while the other 49 respondents (14.45\%) were females. Regarding the job status, 42 employees (12.39\%) were from the top management, 60 individuals were middle level managers (17.7\%), whereas; 162 respondents were supervisor (47.79\%), 66 respondents (19.47\%) were in the position of non-managerial and the remaining 9 respondents (2.65\%) were in the category of others.

Table 1: Demographic profile of the respondents

\begin{tabular}{lcc}
\hline & Frequency & Percent \\
\hline Gender & 290 & \\
Male & 49 & 85.55 \\
Female & & 14.45 \\
Job status & 42 & \\
Top management & 60 & 12.39 \\
Middle manager & 162 & 17.70 \\
Supervisor & 66 & 47.79 \\
Non managerial & 9 & 19.47 \\
Others & & 2.65 \\
Qualification & 1 & \\
Never been to school & 19 & 0.29 \\
Primary school & 63 & 5.60 \\
Preparatory school & 75 & 18.58 \\
Secondary school & 161 & 22.12 \\
University & 20 & 47.49 \\
Others & & 5.90 \\
Income (LYD) & 3 & \\
Less than 500 & 31 & 0.88 \\
501 to1000 & & 9.14
\end{tabular}




$\begin{array}{lcc}1001 \text { to } 1500 & 96 & 28.32 \\ 1501 \text { to } 2000 & 137 & 40.41 \\ 2001 \text { to } 2500 & 50 & 14.75 \\ 2501 \text { and more } & 22 & 6.49 \\ \text { Experience } & & \\ \text { Less than one year } & 7 & 2.06 \\ 1-3 \text { years } & 29 & 8.55 \\ 4-5 \text { years } & 100 & 29.50 \\ \text { More than } 5 \text { years } & 203 & 59.88\end{array}$

Note: $\mathrm{N}=339$

The level of qualification held by the majority of the respondents was a university degree i.e. 161 respondents (47.49\%), the next largest group was secondary school 75 (22.12\%), followed by preparatory school 63 respondents (18.58\%), primary school with 19 respondents (5.6\%), and 5.9\% others. Similarly, when asked about the current income of respondents, it was noted that 3 respondents $(0.88 \%)$ worked with the salary of less than 500 LYD, 31 respondents (9.14\%) were having income range between LYD 501 to 1000; 96 respondents (28.32\%) having income range between LYD 1001 to 1500, whereas 137 respondents (40.41\%) specified their income level as LYD 1501 to 2000. 50 respondents were having income range between LYD 2001 to 2500 and the remaining 22 respondents were having income range of 2501 and more. with regards to experience, it was found that the majority of the respondents possessed advanced qualifications. Only 7 respondents $(2.06 \%)$ were found to have less than a year's experience; 29 respondents had 1 to 3 years' experience, followed by 100 respondents (29.5\%) who had 4 to 5 years of experience. The number of respondents with more than 5 years of experience was 203 (59.88\%).

The study hypothesised a significant influence of HRM practices on social skills and labour productivity in the Libyan oil and gas companies. The hypothesised model was evaluated using goodness fit indices in order to confirm the structural model fit that was further also accepted by Cunningham (2008) who mentioned that support for the hypothesised model can be achieved with an effective and acceptable goodness fit criteria. Structural equation modelling (SEM) was used to confirm the hypothesised model in the form of structural model. According to Byrne (2013), "SEM is particularly valuable in data analysis where the patterns of inter-relationships among the constructs are specified according to a prior established theory. SEM has the flexibility to model relationships amongst multiple criteria and predictors and statistical testing is prioritised empirically through the CFA (Hoe, 2008).

\subsection{Measurement Model}

Measurement model for the underlying constructs that is provided with the path diagram. In each of the measurement models, multiple items are used to measure each underlying factor. However, if items become redundant, the measurement model needs to be re-specified by removing the redundant items (Arbuckle, 2005; Hair, Black, Babin, Anderson, \& Tatham, 2006; Kline, 2005). Parsimonious unidimensional estimation can be achieved by removing the redundant items (Gerbing \& Anderson, 1988). According to the research performed by Yuserrie, Noor Azlinna, and Panigrahi (2014) the discriminant validity is achieved when the model and its constructs are free from redundant items. Thus AMOS software was used to identify the pair of redundant items in the model in terms of high modification indices. In this study, the data set is validated using content validity, construct validity, and convergent validity using structural equation modelling technique. The factor loadings for these measures were all above 0.60 indicating that standardised estimates for these measures were deemed to be statistically significant at $P<0.001$. From the measurement model of the constructs, the discriminant validity criteria is confirmed as the correlation between the constructs does not exceeded 0.85 . 
Figure 2: Measurement model for the constructs

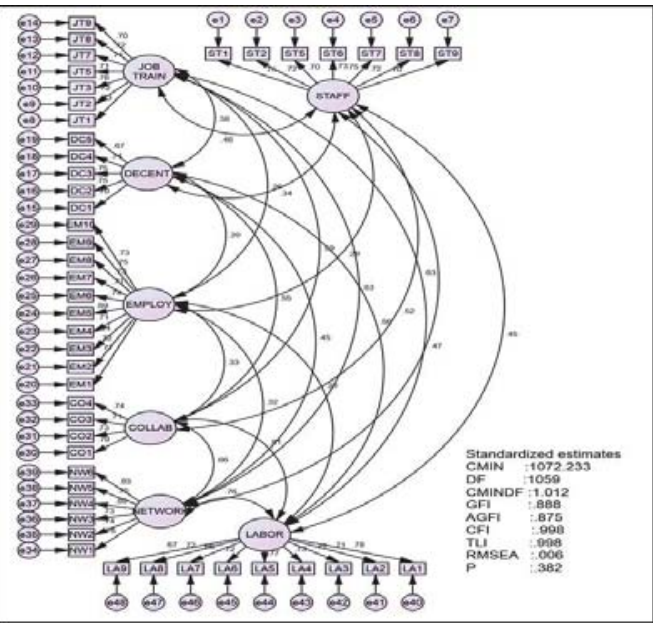

Table 2: Reliability and Validity Test for Measurement Model

\begin{tabular}{|c|c|c|c|c|c|c|}
\hline Exogenous & Path & Endogenous & Estimate & CR & $\alpha$ & AVE \\
\hline Staffing & & & & 0.886 & 0.873 & 0.526 \\
\hline ST1 & $<---$ & STAFF & 0.746 & & & \\
\hline ST2 & $<---$ & STAFF & 0.724 & & & \\
\hline ST5 & $<--$ & STAFF & 0.704 & & & \\
\hline ST6 & $<---$ & STAFF & 0.733 & & & \\
\hline ST7 & $<--$ & STAFF & 0.748 & & & \\
\hline ST8 & $<---$ & STAFF & 0.717 & & & \\
\hline ST9 & $<--$ & STAFF & 0.704 & & & \\
\hline Job training & & & & 0.884 & 0.874 & 0.521 \\
\hline JT1 & $<---$ & JOB_TRAIN & 0.730 & & & \\
\hline JT2 & $<--$ & JOB_TRAIN & 0.725 & & & \\
\hline JT3 & $<--$ & JOB_TRAIN & 0.759 & & & \\
\hline JT5 & $<---$ & JOB_TRAIN & 0.711 & & & \\
\hline $\mathrm{JT7}$ & $<--$ & JOB TRAIN & 0.714 & & & \\
\hline JT8 & $<--$ & JOB TRAIN & 0.716 & & & \\
\hline JT9 & $<--$ & JOB_TRAIN & 0.698 & & & \\
\hline Decentralisation & & & & 0.845 & 0.844 & 0.523 \\
\hline DC1 & $<---$ & DECENT & 0.703 & & & \\
\hline DC2 & $<--$ & DECENT & 0.751 & & & \\
\hline DC3 & $<--$ & DECENT & 0.750 & & & \\
\hline DC4 & $<--$ & DECENT & 0.736 & & & \\
\hline DC5 & $<--$ & DECENT & 0.672 & & & \\
\hline Employee motivation & & & & 0.937 & 0.913 & 0.515 \\
\hline EMP1 & $<--$ & EMPLOYEE & 0.769 & & & \\
\hline EMP2 & $<--$ & EMPLOYEE & 0.716 & & & \\
\hline EMP3 & $<--$ & EMPLOYEE & 0.637 & & & \\
\hline EMP4 & $<--$ & EMPLOYEE & 0.706 & & & \\
\hline EMP5 & $<--$ & EMPLOYEE & 0.688 & & & \\
\hline EMP6 & $<--$ & EMPLOYEE & 0.735 & & & \\
\hline EMP7 & $<--$ & EMPLOYEE & 0.713 & & & \\
\hline EMP8 & $<--$ & EMPLOYEE & 0.728 & & & \\
\hline EMP9 & $<--$ & EMPLOYEE & 0.752 & & & \\
\hline EMP10 & $<--$ & EMPLOYEE & 0.725 & & & \\
\hline Collaboration & & & & 0.831 & 0.830 & 0.551 \\
\hline $\mathrm{CO} 1$ & $<---$ & COLLAB & 0.787 & & & \\
\hline
\end{tabular}




\begin{tabular}{ccccccc} 
CO2 & $<---$ & COLLAB & 0.733 & & & \\
CO3 & $<---$ & COLLAB & 0.707 & & & \\
CO4 & $<---$ & COLLAB & 0.740 & & & \\
Networking & & & & & & \\
NW1 & $<---$ & NETWORK & 0.755 & 0.896 & 0.895 & 0.589 \\
NW2 & $<---$ & NETWORK & 0.740 & & & \\
NW3 & $<---$ & NETWORK & 0.731 & & & \\
NW4 & $<---$ & NETWORK & 0.799 & & & \\
NW5 & $<---$ & NETWORK & 0.752 & & & \\
NW6 & $<---$ & NETWORK & 0.825 & & & \\
Labour productivity & & & & & & \\
LA1 & $<---$ & LABOUR & 0.782 & 0.928 & 0.907 & 0.523 \\
LA2 & $<---$ & LABOUR & 0.714 & & & \\
LA3 & $<---$ & LABOUR & 0.721 & & & \\
LA4 & $<---$ & LABOUR & 0.734 & & & \\
LA5 & $<---$ & LABOUR & 0.771 & & & \\
LA6 & $<---$ & LABOUR & 0.721 & & & \\
LA7 & $<---$ & LABOUR & 0.660 & & & \\
LA8 & $<---$ & LABOUR & 0.723 & & & \\
LA9 & $<---$ & LABOUR & 0.673 & & & \\
\hline
\end{tabular}

Note: C.R - Composite Reliability; AVE - Average Variance Extracted

In the measurement model, it was noticed that the AVE for all the variables were above the required level of 0.50 . Thus, it is confirmed that the criteria of AVE was satisfied. The result on AVE also provided an additional support for convergent validity. It was also possible to provide the discriminant validity between the factors due to positive definite issue of the matrix. Construct validity is confirmed based on goodness-fit-indices Hsieh and Hiang (2004) reported in the earlier section. Evidence of convergent validity is found based on high factor loadings (greater than 0.50 ) of all factors (HolmesSmith, Coote, \& Cunningham, 2006).

\subsection{Structural Model}

In order to confirm that the structural model fit the data, the model was evaluated in the terms of goodness of fit indices. According to Cunningham (2008), a good fit to the sample data provides support for the hypothesised model. For hypotheses testing purposes, parameter estimates together with coefficient values were examined. Parameter estimates are used to generate the estimated population covariance matrix for the model (Tabachnick \& Fidell, 2001). Coefficients' values are derived by dividing the variance estimate by its standard error (S.E). When the critical value (C.R) or Z-value is greater than 1.96 for a regression weight (standardised estimates), the parameter is statistically significant at the .05 levels.After the modification indices and removal of few redundant measured items, Figure 3 shows that the fitness criteria is achieved.

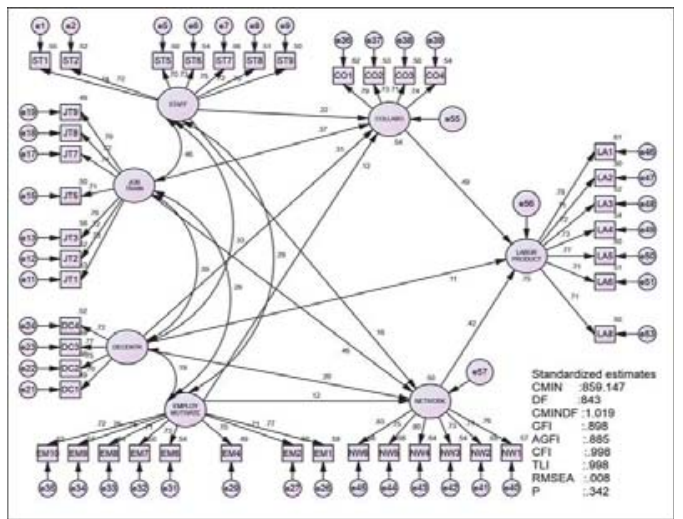

Figure 3: Final Re-specified Model 
Table 4. 34 Standardised Regression Weights for Hypothesised Model

\begin{tabular}{ccccccc}
\hline Endogenous & Path & Exogenous & Estimate & Beta & C.R. & P \\
\hline COLLAB & $<---$ & STAFF & 0.232 & 0.221 & 3.704 & $* \star *$ \\
COLLAB & $<---$ & JOB_TRAIN & 0.370 & 0.351 & 5.571 & $* \star *$ \\
COLLAB & $<---$ & DECENT & 0.391 & 0.323 & 5.376 & $* \star *$ \\
COLLAB & $<---$ & EMPLOY & 0.125 & 0.117 & 2.285 & 0.022 \\
NETWORK & $<---$ & EMPLOY & 0.138 & 0.117 & 2.350 & 0.019 \\
NETWORK & $<---$ & DECENT & 0.279 & 0.209 & 3.719 & $* * *$ \\
NETWORK & $<---$ & JOB_TRAIN & 0.524 & 0.452 & 6.919 & $* \star *$ \\
NETWORK & $<---$ & STAFF & 0.184 & 0.160 & 2.779 & 0.005 \\
LABOUR & $<---$ & COLLAB & 0.532 & 0.501 & 6.915 & $* \star *$ \\
LABOUR & $<---$ & NETWORK & 0.385 & 0.398 & 6.518 & $* \star *$ \\
LABOUR & $<---$ & DECENT & 0.134 & 0.104 & 2.034 & 0.042 \\
LABOUR & $<---$ & STAFF & -0.058 & -0.052 & -1.085 & 0.278 \\
LABOUR & $<---$ & JOB_TRAIN & 0.102 & 0.091 & 1.528 & 0.127 \\
LABOUR & $<---$ & EMPLOY & -0.048 & -0.042 & -1.038 & 0.299 \\
\hline
\end{tabular}

According to Klein, Ettenson, and Morris (1998), the four major fitness indices like GFI, TLI, RMSEA or CFI are used for evaluating the model fit. Similarly, Smith (2006) stated that there must be at least three fitness indices significant in order to confirm the model fit. This study adopts the major fitness indices that are commonly used in research. The absolute values like GFI and RMSEA, incremental values includes CFI, TLI and parsimonious values like chi-square/df were used to confirm the model fit.

An examination of the goodness-of-fit indices showed that the model fitted the data effectively $(X 2=859.147$, $d f=$ 843, $\mathrm{p}=.342$ ). The GFI=.898, AGFI=.885, CFI=.998, TLI=.998, RMSEA $=.008$ and $\mathrm{X} 2 / \mathrm{df}=1.019$. However, absolute fit index value GFI was found to be very near to the acceptable value of greater than 0.90 . According to previous studies performed by (Chang \& Chen, 2009) with GFI $=0.89$ and AGFI $=0.86$, claimed AGFI greater than 0.80 whereas; GFI to be greater than 0.90 . Similarly, (Chau \& Hu, 2001) provided the cut off value of AGFI as above 0.80 . (Tabachnick \& Fidell, 2013) further added, "AGFI value adjusts the GFI based on the degree of freedom and AGFI tends to increase with sample size".

From the square multiple correlation result, it is noted that the model fit criteria are solved and there is a high correlation between the collaboration and networking with labour productivity. With the significant standardised regression weights of all the constructs and items, the overall square multiple correlation was found to be $0.75(75 \%)$ which is considered a very active and important finding of the study.

\section{Conclusions}

The finding of the study also showed that social skills played a mediating effect between HRM practices and labour productivity. The lack of social skills aggregate performance along with individual's personality. Even though the direct link between HRM practices and labour productivity was not significant, with the appropriate usage of social skills i.e. collaboration and networking, employees are able to contribute to enhance labour productivity. Libya as a developing country and Libyan oil and gas companies contributing to the country's GDP must be able to motivate their employees by compensating based on their performance. Employees and managers must have good cooperative skills and work in the field as a team in order to overcome the problems and increase productivity. Furthermore, managers must consider collaboration and networking as a strategy to get the work done in an effective manner without any conflicts among the employees. Social skills was also found to have direct relationship with labour productivity. This indicates that the appropriate usage of social skills can enable the employees to improve their professional knowledge and increase the relationship with other colleagues and managers.

In future research, instead of limiting the survey to top level management, it is suggested to focus on the opinion from employees throughout the oil and gas industry and perform a comparison of the results. It is suggested for the managers to make a checklist in order to target their productivity weaknesses and attempt to fulfil such weaknesses in an effective way. 


\section{References}

Abozed, M., Melaine, Y., \& Saci, K. (2009). The Influence of Work Environmental Factors on Motivation to Transfer Management Training: Case Study of the Libyan Oil Industry. Paper presented at the 4 th Annual Conference Liverpool BEAN.

Arbuckle, J. L. (2005). Amos 6.0 user's guide. Chicago, IL: SPSS: Inc.

Arnold, H. J., \& Feldman, D. C. (1982). A multivariate analysis of the determinants of job turnover. Journal of Applied Psychology, 67(3), 350.

Barney, J. (1991). Firm resources and sustained competitive advantage. Journal of Management, 17(1), 99-120.

Bassanini, A., Garnero, A., Marianna, P., \& Martin, S. (2010). Institutional determinants of worker flows: A cross-country/cross-industry approach: OECD Publishing.

Bindra, N. H. L. D. S. (2008). Human resource planning \& control for energy industry in libya: Meeting the challenge.

Bloom, N., \& Reenen, J. V. (2011). Human resource management and productivity. Handbook of labor economics, 4, $1697-1767$.

Boxall, P., \& Purcell, J. (2011). Strategy and Human Resource Management: Palgrave Macmillan.

Byrne, B. M. (2013). Structural equation modeling with AMOS: Basic concepts, applications, and programming: Routledge.

Chang, H. H., \& Chen, S. W. (2009). Consumer perception of interface quality, security, and loyalty in electronic commerce. Information \& Management, 46(7), 411-417.

Chau, P. Y., \& Hu, P. J. H. (2001). Information technology acceptance by individual professionals: A model comparison approach*. Decision sciences, 32(4), 699-719.

Cunningham, E. (2008). A practical guide to structural equation modelling using Amos. Melbourne: Statsline.

Delaney, J. T., \& Huselid, M. A. (1996). The impact of human resource management practices on perceptions of organizational performance. Academy of management Journal, 39(4), 949-969.

Fallahi, F., Sakineh, S., \& Mehin Aslaninia, N. (2010). Determinants of Labor Productivity in Iran's Manufacturing Firms: With Emphasis on Labor Education and Training.

Farnham, D. (2010). Human Resource Management in Context: Strategy, Insights and Solutions. (3 ed.). London.

Fletcher, C. (2001). Performance appraisal and management: the developing research agenda. Journal of Occupational and Organizational Psychology, 74(4), 473-487.

Gerbing, D. W., \& Anderson, J. C. (1988). An updated paradigm for scale development incorporating unidimensionality and its assessment. Journal of marketing research, 186-192.

Hair, J. F., Black, W. C., Babin, B. J., Anderson, R. E., \& Tatham, R. L. (2006). Multivariate data analysis (Vol. 6): Pearson Prentice Hall Upper Saddle River, NJ.

Hank, K. (2011). Societal determinants of productive aging: A multilevel analysis across 11 European countries. European sociological review, 27(4), 526-541.

Hoe, S. L. (2008). Issues and procedures in adopting structural equation modeling technique. Journal of applied quantitative methods, $3(1), 76-83$

Hogan, R., \& Shelton, D. (1998). A socioanalytic perspective on job performance. Human performance, 11(2-3), $129-144$.

Holbeche, L. (2009). Aligning human resources and business strategy: Routledge.

Holmes-Smith, P., Coote, L., \& Cunningham, E. (2006). Structural equation modeling: From the fundamentals to advanced topics. SREAMS, Melbourne.

Hsieh, Y.-C., \& Hiang, S.-T. (2004). A study of the impacts of service quality on relationship quality in search-experience-credence services. Quality control and applied statistics, 49(6), 687-688.

Huselid, M. A. (1995). The impact of human resource management practices on turnover, productivity, and corporate financial performance. Academy of management Journal, 38(3), 635-672.

Klein, J. G., Ettenson, R., \& Morris, M. D. (1998). The animosity model of foreign product purchase: An empirical test in the People's Republic of China. The Journal of Marketing, 89-100.

Kline, R. (2005). Principles and practice of structural equation modeling. Guilford Press. New York, 59.

Koch, M. J., \& Mcgrath, R. (1996). Improving labor productivity: Human resource management policies do matter. Strategic Management Journal, 17(5), 335-354.

Kozlowski, S. W., \& Klein, K. J. (2000). A multilevel approach to theory and research in organizations: Contextual, temporal, and emergent processes.

McGuckin, R. H., \& Van Ark, B. (2003). Performance 2002: Productivity, Employment, and Income in the World's Economies.

McGurk, S. R., Mueser, K. T., \& Pascaris, A. (2005). Cognitive training and supported employment for persons with severe mental illness: one-year results from a randomized controlled trial. Schizophrenia bulletin, 31(4), 898-909.

Mobbs, P. M., Taib, M., \& Wallace, G. J. (2012). The Mineral Industries of the Middle East. Minerals Yearbook: Area Reports International Review 2010 Africa and the Middle East, 10.

Ogden, T. E., \& Goldberg, I. A. (2002). Research proposals: A guide to success: Academic Press.

OPEC. (2012). Annual Statistical Bulletin.

Outlook, A. E. (2013). Energy Information Administration. United States.

Park, T.-Y., \& Shaw, J. D. (2013). Turnover rates and organizational performance: A meta-analysis. Journal of Applied Psychology, 98(2), 268.

Roudi Fahimi, F., \& Kent, M. M. (2007). Challenges and Opportunities--the Population of the Middle East and North Africa: Population 
Reference Bureau.

Ruël, H., \& Bondarouk, T. (2014). e-HRM Research and Practice: Facing the Challenges Ahead Handbook of Strategic e-Business Management (pp. 633-653): Springer.

Tabachnick, B. G., \& Fidell, L. S. (2001). Using multivariate statistics.

Tabachnick, B. G., \& Fidell, L. S. (2013). Using multivariate statistics (Vol. 6). Boston: Pearson.

Tharenou, P., Saks, A. M., \& Moore, C. (2007). A review and critique of research on training and organizational-level outcomes. Human Resource Management Review, 17(3), 251-273.

Thomas, H. R., Maloney, W. F., Horner, R. M. W., Smith, G. R., Handa, V. K., \& Sanders, S. R. (1990). Modeling construction labor productivity. Journal of Construction Engineering and Management, 116(4), 705-726.

Thongsennheuang, S. (2012). To Study the Effect of Moderator of Social Skills on the Changing Between Managerial Skills and SME Performance. University of the Thai Chamber of Commerce.

Tsang, H. W. (2003). Augmenting vocational outcomes of supported employment with social skills training. Journal of Rehabilitation, 69(3), 25.

Woodrow, C., \& Guest, D. E. (2014). When good HR gets bad results: exploring the challenge of HR implementation in the case of workplace bullying. Human Resource Management Journal, 24(1), 38-56.

Wright, P. M., \& McMahan, G. C. (1992). Theoretical perspectives for strategic human resource management. Journal of Management, 18(2), 295-320.

Yuserrie, Z., Noor Azlinna, A., \& Panigrahi, S. (2014). Investigating Key Determinants for the Success of Knowledge Management System (KMS) in Higher Learning Institutions of Malaysia using Structural Equation Modeling. The International Journal Of Humanities \& Social Studies (IJHSS), 2(6), 202-209.

\section{Appendix}

\section{Staffing}

1. Recruitment \& selection system followed in our organization is well defined

2. In our organization, line managers and HR managers participate in recruitment \& selection

3. Valid and standardized tests are used in the selection process of employees

4. Selection system in our organization selects those having the desired knowledge, skills and attitudes

5. Our organization uses comprehensive selection process before rendering a decision

6. The organization uses assessment centers for selection

7. Our organization uses unbiased test and interviewing techniques for employee selection

8. Our organization selects employees without any bias

9. We have strong merit criteria for employee selection

10. We use attitude and desire to work in a team and individual as a criterion in employee selection

\section{On Job Training}

1. Our organization conducts Extensive training programs for Employees

2. Employees at each job normally go through Training programs every year

3. Training needs are identified through a formal performance appraisal mechanism

4. There are formal training programs to teach new employees the skills they needed

5. Training needs identified are realistic, useful and based on the organizational strategy.

6. There are formal training evaluation methods to assess the effectiveness of the training

7. The organization has a system for calculating the cost and benefit of training

8. Training has helped reduce employee turnover in our organization

9. Training has resulted in higher employee performance in our organization

10. Training has resulted in higher productivity and financial returns for the organization.

\section{Decentralized Decision}

1. There can be little action taken until a supervisor approves a decision

2. People who want to make their own decisions would be quickly discouraged

3. Even small matters must be referred to someone higher up for approval

4. employees must ask their supervisors before doing almost anything

5. any decisions employees make must have their bosses' approval

\section{Employee Motivation}

1. Compensation offered by our organization matches the expectancy of employees

2. In our organization, salary and other benefits are comparable to the market

3. In our organization, compensation is decided on the basis of competence of the employee

4. In our organization, profit sharing is used as a mechanism to reward higher performance

5. Our organization offers both financial and non-financial rewards without discrimination 
6. Compensation plan is revised accordingly with the economic situation

7. Take home pay is enough for my family and me

8. My last year's salary raise was better than the previous one

9. Salary increase in my organization is primarily based on seniority

10. The compensation for all employees is directly linked to their performance

\section{Collaboration}

1. I have cooperation among the people at work.

2. I am in teamwork and group problem solving.

3. I create the conditions for brainstorming the

4. Strategic issues and actions.

5. I create credible processes for collaborating.

\section{Networking}

1. I use company events to make new Contacts.

2. I catch up with colleagues from other departments about what they are working on.

3. I use my contacts with colleagues in other departments in order to get confidential advice in business matters.

4. I accept invitations to official functions or festivities out of professional interest.

5. I ask others to give my regards to business acquaintances outside of our company

6. I exchange professional tips and hints with acquaintances from other organizations

\section{Labor Productivity}

1. Quality and quantity of our employees' work output has improved.

2. Coming up with new ideas is appreciated in the organization as labor productivity.

3. Most of the employees achieved organizational goals of last 5 years.

4. Over all employees targets achievements has improved over the last 5 years.

5. Employees feel happy to work in teams.

6. Majority of our employees can work independently and they give high performance.

7. Employees in our organization have been enabled to make decisions well.

8. Employees' communication skills have been improved in this organization.

9. Employees' competencies are in line with the organizational operational and strategic goals. 